\title{
Rock Dump Design to Limit Potential Acid Drainage
}

\author{
D.J. Williams The University of Queensland, Australia
}

P. Scott HLA ENSR, Australia

D. Johnston Zinifex Century Mine, Australia

G. Lee Zinifex Century Mine, Australia

\begin{abstract}
The design of rock dumps comprising reactive rock should aim to limit the potential for the release of acid drainage to the environment. This requires the recognition of a number of contributing factors. Clean runoff should be kept separate from mine water, by diverting runoff upslope of the dump and lining surface drainage channels to be buried by the dump with benign rock. There is a need to selectively place benign and reactive rock to encapsulate the reactive rock. The rock dump hydrology needs to be understood, in particular the wetting-up of the dump by rainfall infiltration, in the context of the climatic setting, the surface hydrology, and the groundwater regime. Finally, a low percolation cover is required over the top of the dump, and side slopes should not be underlain by reactive rock and should be designed to minimise erosion. The paper describes the application of these principles to the design of a new rock dump being constructed at an existing open pit mine that has experienced acid drainage from a past rock dump. The design of the new rock dump to limit the potential for acid drainage required a change in the mind set for rock dump construction, and imposed a number of constraints on site preparation, construction of the rock dump, and the sequencing of rock dumping, which had to be overcome.
\end{abstract}

\section{Introduction}

Zinifex Century mine in north Queensland, Australia, are extending the existing West Waste Rock Dump (WWRD) to accommodate future waste rock production from their open pit. In view of past acid rock drainage (ARD) from the existing South Waste Rock Dump (SWRD), the mine required a dump design for the WWRD extension to meet their long-term economic and environmental objectives, including minimising operational and post-closure costs and the potential for ARD from the extended dump.

\subsection{Site location}

The Zinifex Century zinc-lead mine is located $250 \mathrm{~km}$ north-north-west of Mount Isa, in Queensland, Australia. The topography of the site comprises numerous small undulating hills and ridge lines separated by drainage basins. The site vegetation is low and sparse, as is typical of the semi-arid environment of northern Australia. The existing WWRD is located immediately north-west of the current open pit, and the WWRD extension will continue south of the existing WWRD. The WWRD extension is currently planned to fill a catchment surrounded by natural ridge lines draining to, and immediately west of, Page Creek, as shown in Figure 1.

\subsection{Design objectives}

A key objective of the design of the WWRD extension was to minimise the potential for environmental harm to Page Creek, involving the following steps:

- Identification of the environmental risks associated with dump construction.

- Assessment of the quality of the potential seepage from waste in the WWRD extension.

- Proposing erosion and sediment control measures and management strategies.

- Development of strategies to manage identified environmental risks. 


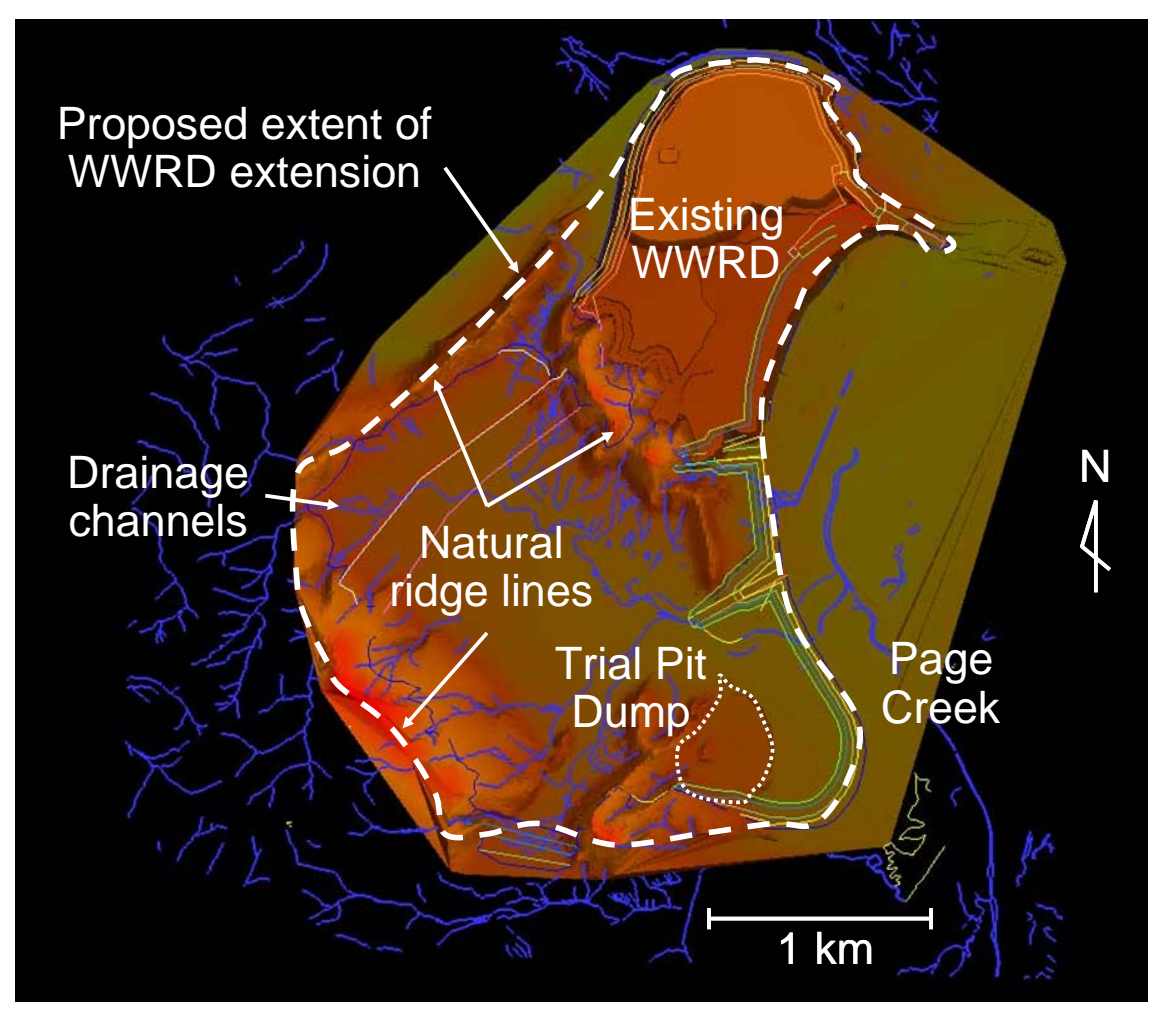

Figure 1 Location of existing WWRD and WWRD extension west of Page Creek

- Development guidelines for the scheduling and placement of non-acid forming (NAF) and potentially acid forming (PAF) waste rock in the WWRD extension to minimise the potential for environmental harm.

- Identification of the potential for excess NAF waste rock designed for the WWRD to be sent to the SWRD to help manage existing acid rock seepage issues.

- Development of a plan to pass surface water through the WWRD extension catchment to minimise the potential to cause environmental harm.

- Development of a strategy to reduce oxidation of PAF waste rock by limiting water infiltration through these materials.

- Identification of suitable monitoring techniques and locations to enable measurement of performance-based water quality objectives.

- Stabilisation of the existing acid-generating Trial Pit Dump within the WWRD extension footprint and its incorporation into the dump design.

- Minimisation of acidic runoff during the operational phase and prior to completion of PAF cells of the WWRD extension.

\section{$2 \quad$ Site setting}

An understanding of the physical and climatic setting of the site aids in the identification of environmental opportunities and constraints for waste dump construction at Century mine. A brief overview of these follows.

\subsection{Geology and groundwater regime}

The existing WWRD and extension lie immediately west of the Termite Range fault zone with Cambrian limestone in the northern third of the dump and units of the Proterozoic Riversleigh Formation in the 
remainder. Rock outcrops in the north, central and southern regions of the dump footprint, separated by alluvium and colluvium. The northern limestone outcrop is located beneath the existing WWRD. The central portion of the WWRD extension currently appears as a ridge line composed of tuffaceous sandstone, carbonaceous shale and siltstone. The southern outcrop is composed of thickly-bedded sandstone, shale and siltstone.

Groundwater levels are generally within several metres of the natural surface. The Cambrian limestone, which outcrops in places across the site, is a permeable aquifer, with total dissolved solids ranging from 400 to $500 \mathrm{mg} / \mathrm{l}$, and low sulphate and metal concentrations. In contrast, the underlying Proterozoic aquifer, which also outcrops in places across the site, has total dissolved solids ranging from 560 to $1050 \mathrm{mg} / \mathrm{l}$, and high sulphate and relatively elevated metal concentrations. The permeability of the Proterozoic sedimentary rock is low $\left(3 \times 10^{-8}\right.$ to $\left.1 \times 10^{-5} \mathrm{~m} / \mathrm{s}\right)$, and groundwater flows are predominately along secondary features such as cracks, fractures and joints.

\subsection{Soils}

Due to the widespread presence of rock outcrops across the site and the near proximity to the surface of rock elsewhere, the soil cover is generally non-existent to thin. Where soil cover does exist it is weakly-developed and includes angular rock fragments. The soil is composed of alluvium and colluvium. Soil types include ferruginous screed, immature black soil and thin soils in ephemeral waterways and floodplains derived from sandstone, siltstone and carbonaceous shale.

\subsection{Topography}

The main topographical features of the site, which dictate the surface hydrology of the WWRD extension, include:

- The central ridge line to RL 1200 to $1210 \mathrm{~m}$ AHD, dropping at its eastern end to RL $1160 \mathrm{~m}$ AHD, and separating the existing WWRD from the WWRD extension.

- The western boundary ridge line at RL 1180 to $1200 \mathrm{~m}$ AHD.

- The south-western plateau to RL 1200 to 1270 m AHD.

- The southern hill near the Trial Pit Dump.

- The existing WWRD to the north of the footprint.

The ridge lines and hills generally rise about 50 to $85 \mathrm{~m}$ above the central valley and adjacent Page Creek.

\subsection{Catchments and surface hydrology}

The footprint of the WWRD extension drains largely to Page Creek, with some runoff draining between ridge lines to the north-west, as shown in Figure 1. The extensive pattern of drainage channels within the WWRD extension footprint shown in Figure 1 includes two creek systems, in the central and southern sections of the footprint. These join and drain into Page Creek. The physical features of the central and southern creek systems upstream of the WWRD extension footprint are given in Table 1.

Table 1 Physical features of creek systems upstream of WWRD extension footprint

\begin{tabular}{lcccc}
\hline Catchment & $\begin{array}{c}\text { Area } \\
\text { (ha) }\end{array}$ & $\begin{array}{c}\text { Length } \\
\text { (m) }\end{array}$ & $\begin{array}{c}\text { RL at upper edge of WWRD extension } \\
\text { (m AHD) }\end{array}$ & $\begin{array}{c}\text { RL at Top of Catchment } \\
\text { (m AHD) }\end{array}$ \\
\hline Central & 41.9 & 977 & 1165.8 & 1218.6 \\
Southern & 35.4 & 1,083 & 1167.5 & 1252.1 \\
\hline
\end{tabular}




\subsection{Rainfall and runoff}

Monthly rainfall data for Lawn Hill, located in close proximity to Century mine, is available from 1889, from which the average annual rainfall is $544 \mathrm{~mm}$, with a dry season from April to September and a wet season from October to March. January and February account for about 50\% of total rainfall. In recent years, Century mine has experienced lower than average annual rainfall of about $400 \mathrm{~mm}$, falling on an average 40 days/year.

\section{Risk identification and management}

The risk of ARD is a function of the proportion of PAF to NAF waste rock, the climate, and the exposure of PAF waste rock to oxygen and water. Acidic seepage from a rock dump can percolate into the foundation, potentially impacting any groundwater resources, and/or can seep from the toe of the dump potentially impacting both surface and ground waters downstream.

The design of the WWRD extension drew from experience of past rock dumps at Zinifex Century mine. The completed North Waste Rock Dump (NWRD) is located almost entirely on limestone and, being completed first, comprised largely limestone waste rock. No toe seepage has been observed from the NWRD due to the high permeability of the limestone foundation. Foundation seepage would likely be non-acidic and would ultimately drain to the open pit. The SWRD, which is still under construction, is located on both limestone and low permeability Proterozoic units and comprises considerable exposed PAF waste rock. It has generated some ARD, some of which has emerged as toe seepage. The existing WWRD comprises a mix of NAF and PAF waste rock and is located largely on a permeable limestone foundation. No evidence of acidic seepage from the toe of the existing WWRD has been observed. However, the WWRD extension will be located largely on low permeability Proterozoic units, which would promote toe seepage.

The classification of the Century mine open pit waste rock, lessons learnt from the SWRD, and the potential environmental risks posed by the WWRD, and their management, are discussed in the following paragraphs.

\subsection{Waste rock classification}

The waste rock generated by the Century mine open pit was categorised by Environmental Geochemistry International (EGi, 1997) into three types:

- Type I - acid neutralising, comprising shallow, competent limestone and carbonate breccia.

- $\quad$ Type II - NAF, comprising deeper, non-competent siltstone and sandstone.

- $\quad$ Type III - PAF, comprising shallow and deep shale.

However, only limited Type II waste rock has been encountered to date, and in practice the waste rock has been selectively placed as Type I and Types II and III combined.

\subsection{Lessons learnt from the SWRD}

The SWRD was constructed from about July 1998, and is to be raised in three benches of $16 \mathrm{~m}, 16 \mathrm{~m}$ and $32 \mathrm{~m}$ to a maximum height of $64 \mathrm{~m}$. To July 2006 it had reached an average height of $55 \mathrm{~m}$, and comprised about $50.5 \mathrm{Mm}^{3}(65 \%)$ of Type I waste rock (acid neutralising limestone, mainly in the base and sides), $0.9 \mathrm{Mm}^{3}$ (1\%) of Type II waste rock (NAF siltstone and sandstone), and $25.9 \mathrm{Mm}^{3}$ (34\%) of Type III (PAF shale, mainly in the top centre). The approximate SWRD construction sequence, based on assessments from annual aerial photographs from 1998 to 2006, is summarised in Table 2.

As can be seen from Table 2, the majority of the acid neutralising limestone, which was excavated at shallow depth in the open pit, was located in the bottom bench of the SWRD, and the deeper shale was placed above it, with limited cover of limestone provided around the sides of the shale benches when it was available. As a result, the PAF shale is exposed to oxidation and rainfall infiltration, generating ARD.

Mildly acidic, saline seepage occurs from the western toe of the SWRD, with a $\mathrm{pH}$ of about 6.5 and total dissolved solids ranging from about $7000 \mathrm{mg} / \mathrm{l}$ during the wet season to about $8100 \mathrm{mg} / \mathrm{l}$ during the dry season. 
Table 2 Approximate SWRD construction sequence

\begin{tabular}{cl}
\hline Aerial Photograph Date & Dumping \\
\hline July 1998 & None \\
July 1999 & $80 \%$ of Bench 1 (all limestone), $30 \%$ of Bench 2 (some shale) \\
July 2000 & $100 \%$ of Bench $1,80 \%$ of Bench $2,15 \%$ of Bench 3 (mainly shale) \\
July 2001 & $100 \%$ of Bench $2,30 \%$ of Bench 3 (mainly shale) \\
July 2002 & $50 \%$ of Bench 3 (mainly shale) \\
July 2003 & $65 \%$ of Bench 3 (mainly shale) \\
July 2004 & $70 \%$ of Bench 3 (mainly shale) \\
July 2005 & $75 \%$ of Bench 3 (mainly shale) \\
July 2006 & $80 \%$ of Bench 3 (to an average total height $58 \mathrm{~m}$ )
\end{tabular}

The seepage rate varies seasonally and in response to rainfall events from about $1 \mathrm{l} / \mathrm{s}$ during the dry season to $120 \mathrm{l} / \mathrm{s}$ following prolonged heavy rainfall. High seepage rates are short-lived and the average seepage rate is perhaps $11.6 \mathrm{l} / \mathrm{s}$ on an annual basis. The total toe seepage is therefore about $365 \mathrm{Ml} /$ year or $365 \mathrm{~m}^{3} /$ year. This is equivalent to an average of $0.15 \mathrm{~mm} / \mathrm{year} / \mathrm{m}^{2}$ of the 250 ha SWRD, or only $0.04 \%$ of the current average annual rainfall of about $400 \mathrm{~mm} /$ year; a very low rate.

Since the SWRD has yet to wet-up sufficiently from rainfall infiltration to generate "continuum breakthrough", the total base seepage is likely to be of the order of $2 \%$ of annual rainfall, since the majority of the rainfall infiltration will go into storage within the dump (Williams and Rohde, 2008). The majority of the base seepage is therefore percolating into the foundation, with little emerging at the toe of the dump. This estimated total base seepage of $2 \%$ of annual rainfall is supported by measured groundwater mounding beneath the SWRD of up to $3 \mathrm{~m}$ around the toe of the dump (to about $3 \mathrm{~m}$ below natural surface) and up to $6 \mathrm{~m}$ beneath the centre of the dump, which fluctuates seasonally. The seepage quality would be expected to deteriorate over time as more oxidation products are produced and flushed from the dump, and the rate would be expected to increase by about an order of magnitude as the dump were allowed to continue to wetup in the absence of an effective low percolation cover.

\subsection{Environmental risks}

Environmental risks posed by the WWRD include ARD, dump slope erosion and sediment mobilisation, and ongoing acidic seepage from the Trial Pit Dump.

\subsubsection{Trial Pit Dump}

The Trial Pit Dump contains the waste rock arising from the mining of a small trial pit prior to full-scale mining commencing in 1998. It was located within the footprint of the WWRD extension due to its proximity of the Trial Pit and because this footprint was considered sterile of potential ore reserves. This site is a current source of ARD due to PAF waste rock being placed at or near the surface of the dump and subsequently oxidising. To reduce ARD release from this dump, the PAF waste rock needs to be effectively encapsulated as part of the WWRD extension.

\subsubsection{Acid rock drainage}

Acid rock drainage occurs as a result of the oxidation of sulphide-bearing PAF waste rock in the presence of oxygen and water, and includes the potential release to the environment of acid, metals and salts from the WWRD. Prolonged atmospheric exposure of sulphidic waste rock will increase the degree of oxidation and hence the potential for ARD. Hence this risk is best managed by reducing the exposure time of placed sulphidic waste rock and minimising the amount of water that can reach PAF waste rock. 
Progressively encapsulating PAF waste rock with NAF material, covering the top surface of completed cells of PAF waste rock with an effective low percolation store/release cover within 1 to 2 years of dumping, and preventing the storage of PAF waste rock beneath outer dump slopes will aid in reducing exposure time. Store/release covers (Williams et al., 2006) serve to store the wet season rainfall within an overlying "rocky soil mulch" layer, mounded to prevent runoff, and release it through evapotranspiration during the wet season. Critical components of a store/release cover are a sealing layer at the base of the cover to "hold-up" infiltrating rainfall, preventing it from being lost to deep drainage and retaining it for later release, and a sustainably vegetated surface to remove the stored rainfall. Store/release covers of the order of $2 \mathrm{~m}$ thick have been demonstrated to be effective in seasonal, semi-arid climates similar to that at Century mine (Williams et al., 2006).

Maintaining clean water separation from mine water is effective in minimising the volume of water that may come into contact with PAF waste rock.

\subsubsection{Dump slope erosion and sediment mobilisation}

Erosion of dump slopes and sediment mobilisation results from slope surface treatments susceptible to erosion by wind and/or rainfall runoff. Wind erosion mainly occurs during dumping and as a result of mine vehicle traffic. Century mine regularly spray haul roads for dust suppression and to reduce sediment mobilisation.

Dump slopes covered with fine-grained materials such as topsoil are particularly prone to erosion by rainfall runoff. The limited topsoils available at Century mine have a high silt content and are very prone to erosion by wind and rainfall runoff. To minimise erosion loss, dump slopes should be armoured with coarse-grained materials, with topsoil amendment to promote moisture retention and some vegetation. At Century mine, limestone and sandstone would be suitable for erosion protection.

\subsection{Resources at risk}

Resources at risk include surface and ground waters, terrestrial surfaces and soils, and the natural landform.

\subsubsection{Contamination of surface water}

Surface water can be contaminated both during and following dump construction with physical and chemical contaminants. Physical contaminants include suspended solids and particulates that form turbid waters and sediments as a result of surface runoff. This can smother creek beds and banks and increase turbidity. Chemical contaminants can arise from surface runoff over the dump or seepage from the toe of the dump. They could include ARD in the form of salts, acidic/basic waters or dissolved metals, generally resulting from the oxidation of exposed PAF waste rock. Management options include reducing exposure of the PAF waste rock to oxidation, minimising infiltration through PAF waste rock, limiting the transport of ARD to and along natural drainage channels buried beneath the dump, and entrapment of ARD generated during dump construction in detention basins and bunds. Buried natural drainage channels and gullies could be lined with limestone, ideally extended to the final height of the dump or capped with a sealing layer to limit the mixing of mine water with clean water flowing beneath the dump from higher natural elevations. If water mounds along these channels there is a greater risk of clean water mixing with mine water.

\subsubsection{Contamination of groundwater}

Groundwater may be contaminated with ARD from PAF waste rock, where a transport medium and pathway exist. Reducing the exposure of PAF waste rock to oxidation is the best form of management. Once PAF waste rock is oxidised, minimising infiltration through it will reduce the mobilisation of ARD. Clean water travelling along buried natural drainage channels and percolating into the foundation should be isolated from mixing with mine water. While the limestone at Century mine is permeable, for the low permeability Proterozoic units, fault lines and fractures represent the most likely pathways to the groundwater. 


\subsubsection{Contamination of terrestrial surfaces and soils}

The terrestrial environment may be at risk when contaminants are deposited directly on the natural surface or when they rise up through the regolith driven by evaporation. Such material may be washed, wind blown or purposefully dumped outside the rock dump footprint.

\subsubsection{Visual impact on the natural landform}

When the dump has been completed it should ideally mimic the natural landform as this is the most stable landform for the region and will deliver the best results for aesthetic and environmental rehabilitation. This can be achieved by designing finished dump landforms to have similar heights, saddles and valleys to the surrounding ridge lines. The slope and shape of the dump sides should also approximate the natural ridge line morphology.

\subsection{Monitoring risk}

In any environmental risk management programme it is necessary to monitor performance to assess the effectiveness of the program. This provides sound justification for adjustment to be made during dump construction as required and early detection of issues as they arise. Insufficient or inappropriate monitoring can result in late detection of issues that can cause damage to the environment and be costly to remedy. Monitoring is required for surface and ground water resources, for physical and chemical contaminants as well as flow volumes.

The placement of monitoring devices for groundwater should include sites in close proximity above and below the hydraulic gradient of groundwater flow beneath the WWRD extension. Additionally, monitoring sites can be placed in the existing WWRD and sections of the WWRD extension are completed to monitor for hydraulic mounding as well as contamination of surface and ground waters.

\section{$4 \quad$ Design and construction of WWRD extension to minimise risk}

The design and construction of the WWRD extension to minimise the risks to the environment and resources are discussed in the following paragraphs.

\subsection{Mass balance}

The WWRD extension is being designed to accommodate an anticipated $101 \mathrm{Mm}^{3}$ of waste rock and will ultimately cover an area of 286 ha. With this capacity, the top surface of the dump when finished will vary in height from RL $1185 \mathrm{~m}$ AHD to the north of the central ridge line to RL $1200 \mathrm{~m}$ AHD to the south. The projected split between the three waste rock types to be stored in the WWRD extension is estimated to be $75 \%$ of Type I limestone, $11.5 \%$ of Type II NAF, and $13.5 \%$ of Type III PAF shale, providing ample limestone and Type II waste rock for encapsulating the relatively small proportion of PAF shale. SURPAC modelling indicates that the total limestone requirement of the WWRD extension is $41.5 \mathrm{Mm}^{3}$, accounting for about $55 \%$ of the projected limestone quantity available of $75.8 \mathrm{Mm}^{3}$, representing a healthy margin.

However, the mine may require some of the limestone destined for the WWRD extension to be diverted to the SWRD to encapsulate shale in the process of completing and covering this dump, or that some of the shale destined for the SWRD be placed in the WWRD extension. As a result, some flexibility in the design of the WWRD extension is required to accommodate a possible higher total volume of waste rock (of up to $115 \mathrm{Mm}^{3}$, requiring a slight increase in the height of the dump), and a relatively higher proportion of shale (up from the projected $13.6 \mathrm{Mm}^{3}$ to as much as $39.4 \mathrm{Mm}^{3}$ ) than is currently anticipated.

\subsection{Base treatment of WWRD extension}

Topsoil from the base of the WWRD extension footprint has been stripped and stored, for later use, at an elevation where it is unlikely to be washed into Page Creek. The topsoil stockpile will be vegetated to limit dusting and to preserve its organic content and natural seed bank. Following topsoil stripping, a minimum $2 \mathrm{~m}$ layer of limestone will be placed over the WWRD extension footprint to act as a neutralising base for any flows of clean water across the buried natural surface. 


\subsection{Treatment of natural drainage channels and gullies}

Along the natural drainage channels within the WWRD extension footprint, including gullies down the ridge lines, limestone will be placed to the final height of the dump, where possible. The width of the placed limestone will need to be a minimum of $80 \mathrm{~m}$ to ensure safe mine haul truck movements. Where full height limestone placement is not possible, the limestone-lined channels will be capped with a sealing layer to limit the mixing of mine water from above. This will provide a conduit for the flow of clean underflow beneath the dump. This is illustrated in Figure 2.

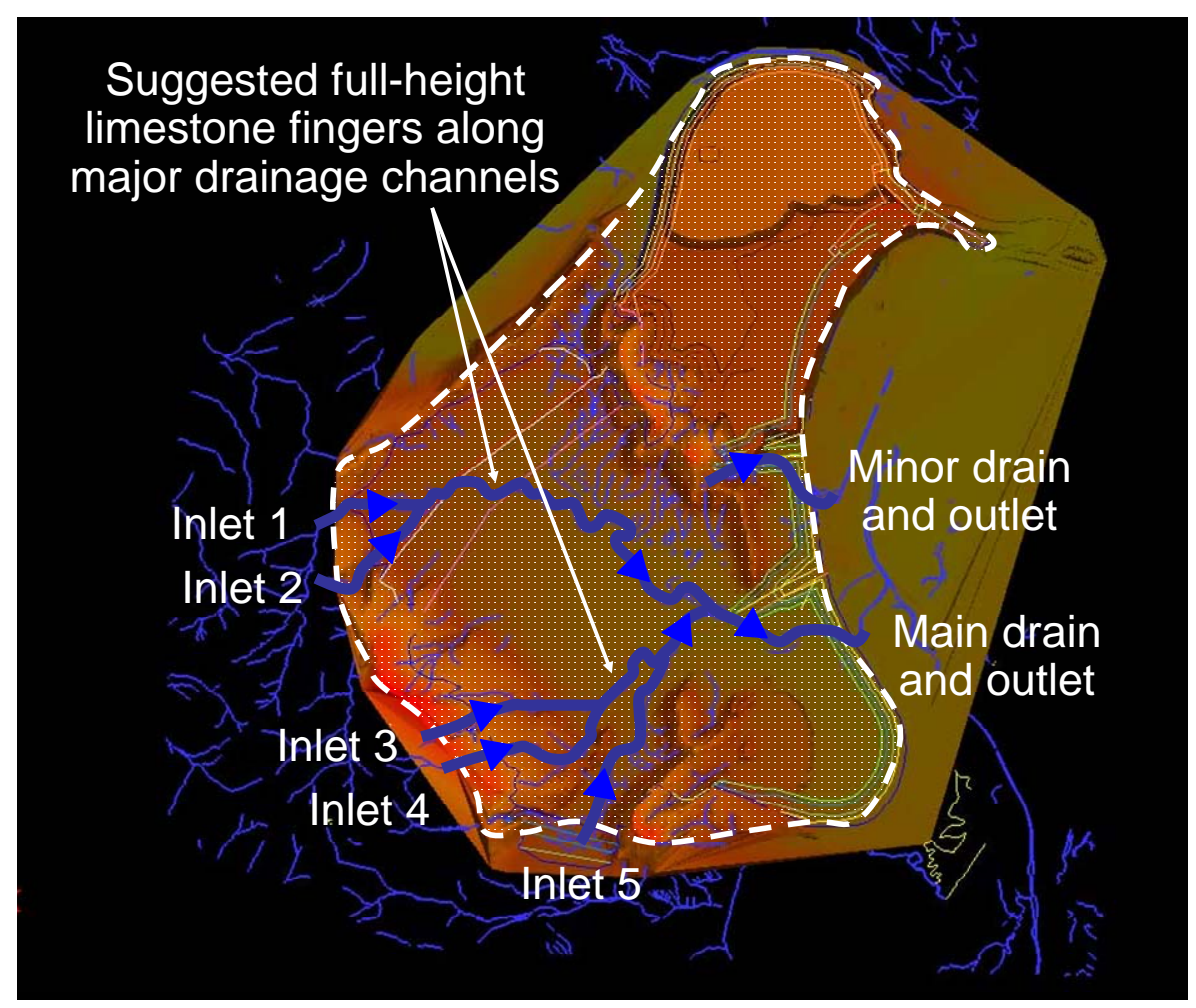

Figure 2 Suggested limestone fingers within WWRD extension footprint

Storm runoff will initially be stored in the limestone fingers along the buried natural drainage channels before breaking through at the downstream toe of the dump to enter Page Creek. By the time breakthrough occurs at the low points of the dump toe, any possible acidic seepage would be expected to be neutralised, and if ARD has been prevented from forming then salinity is anticipated to be at background levels in the seepage. A $1 \mathrm{~m}$ height of limestone would have capacity to store up to $200 \mathrm{~mm}$ of water prior to breaking through.

\subsection{Dump perimeter treatment}

In order to encapsulate PAF waste rock, limestone bunds are required to form the dump perimeter where there is no ridge line to contain the dump. Similar to the limestone drainage channels, these bunds will need to be wide enough to be trafficable by mine haul trucks and will be constructed using limestone (Type I waste rock), or NAF waste rock (Type II) if limestone is not available. As with the limestone fingers used in the buried natural drainage channels, there is a risk of having insufficient suitable waste rock for their construction at the time required, requiring superior mine planning. A further risk is that the bunds are not designed and constructed sufficiently wide to prevent rainfall infiltration on the downstream face from reaching the PAF waste rock on the upstream side. For angle of repose $\left(37^{\circ}\right.$ or $\left.1.3 \mathrm{H}: 1 \mathrm{~V}\right)$ downstream faces, the base width of the perimeter bund should be at least twice their vertical height. 


\subsection{PAF cells}

Encapsulated PAF cells need to be designed to store PAF shale to minimise potential ARD. This is achieved by limiting exposure of the PAF shale to atmospheric oxygen and rainfall infiltration, requiring that the cells ideally be constructed progressively to their final height, encapsulating the PAF shale, and covered with a low percolation store/release cover as soon as practicable. An additional need is to contain the existing ARD from the Trial Pit Dump, located in the lower south-east corner of the WWRD extension footprint, within a PAF cell.

Four PAF storage cells are proposed, separated by the limestone-lined major drainage channels and natural ridge lines within the WWRD extension footprint, located within the areas shown in Figure 3. The four cells could provide capacity for the maximum likely volume of PAF shale to be contained of $39.4 \mathrm{Mm}^{3}$. The order of filling of these cells will primarily be governed by the economics of waste rock haulage and the engineering limitations of dump construction. Ideally, the cells would be filled and covered progressively in the numerical order of the areas shown in Figure 3. Any seepage from the PAF cells should be collected in internal ponds within the WWRD extension footprint and evaporated.

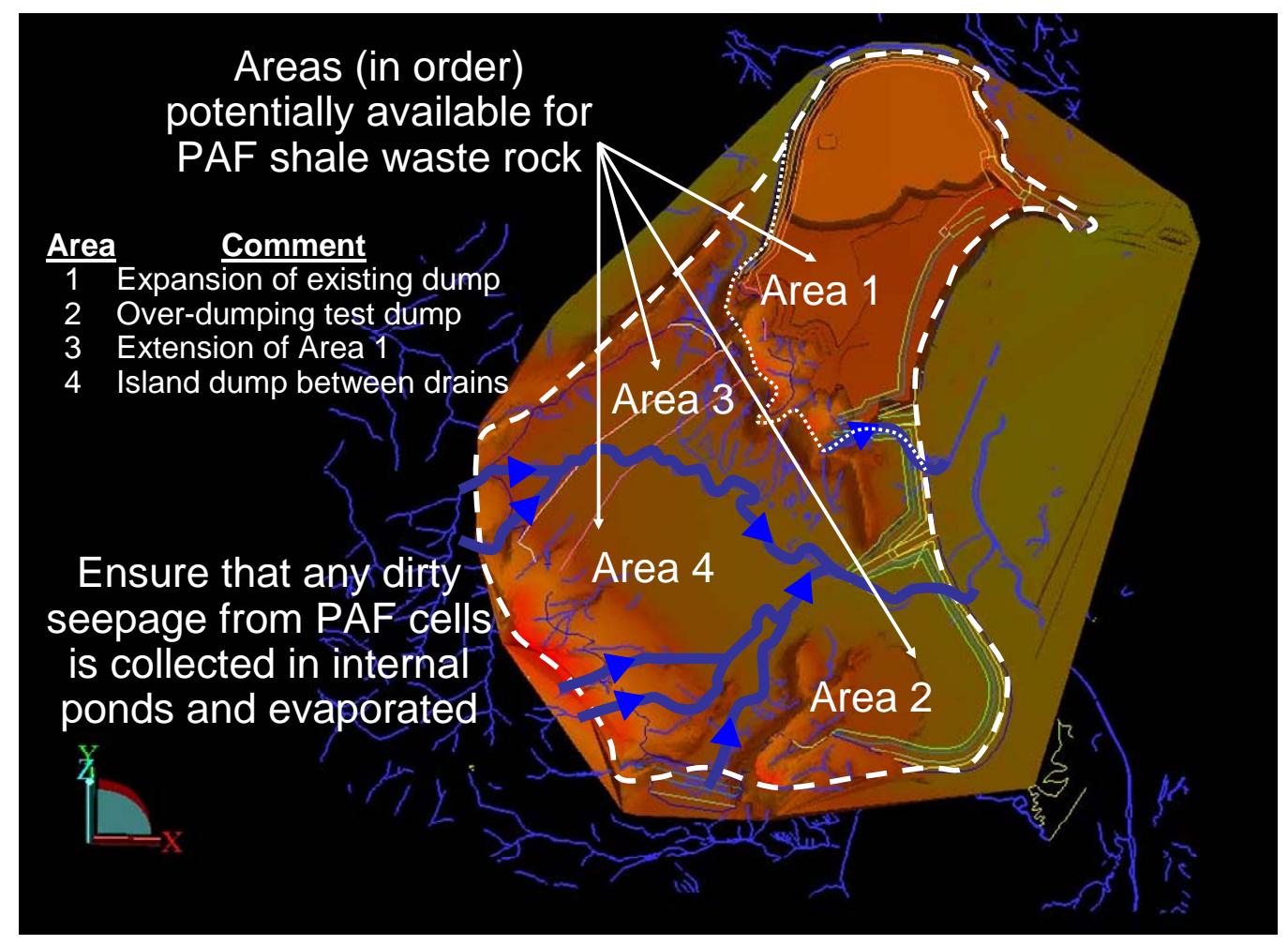

Figure 3 Suggested locations and filling/covering order for PAF cells

\subsection{Store/release top cover}

Low percolation store/release covers are to be progressively built as PAF cells are completed, to reduce the likelihood of mine water storage and seepage occurring. Rainfall infiltration will initially be largely held in storage within the cells, and it is critical to ensure that they do not wet-up sufficiently to cause continuum breakthrough. The store/release cover system has been successfully demonstrated at Kidston in a semi-arid climate of North Queensland to limit percolation to $<1 \%$ of incident rainfall over 10 years (Williams et al., 2006). Based on this experience, the proposed store/release cover design for Century mine will comprise a nominal $0.5 \mathrm{~m}$ thick sealing layer, and a nominal $1.5 \mathrm{~m}$ thick rocky soil mulch layer to capture all rainfall and support a native shrub, tree and grass cover.

Provision will be made for the temporary storage and diversion of rainfall runoff from the natural catchments upslope of the WWRD extension. At the tops of each natural gully, storage volumes will be provided, which drain into the limestone infills that pass through the dump. 


\subsection{Treatment of dump slopes}

The natural ridges, gullies and slope profiles give a good indication of landform stability, which final constructed dump slopes should mimic, and this will also ensure aesthetically acceptable final landforms. This may include mimicking the concave natural slope cross-sections and swales in plan, including steep rock-lined slopes towards crest tops and down gullies and flatter slopes towards the toe and on ridge lines. This is illustrated in plan in Figure 4.

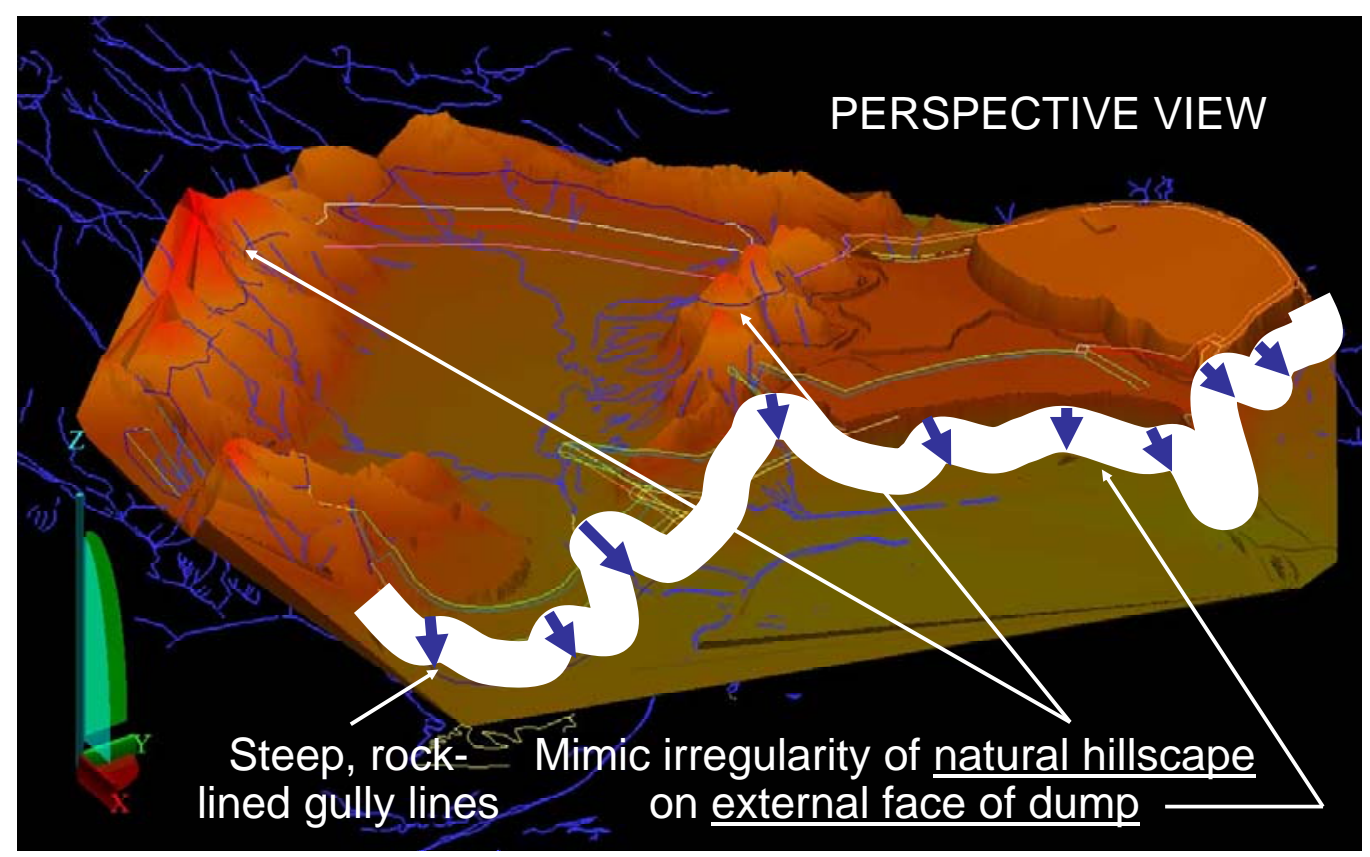

Figure 4 Dump slopes mimicking natural landforms in plan

\subsection{As-constructed design modifications to date}

As-constructed modifications to the design of the WWRD extension to date have included the following:

- Placement of a $2 \mathrm{~m}$ base layer of limestone would require paddock-dumping, which slows dumping operations, and the base layer was increased to a minimum of $5 \mathrm{~m}$ thick to allow more rapid placement by end-dumping.

- To limit rainfall infiltration into the dump during and after construction, trafficked limestone flat surfaces are being sloped towards limestone linings against natural ridge lines, which encourages runoff and the seepage of the clean runoff through limestone and/or into the natural ground.

- Due to the shortage of clayey soils at the site for sealing purposes, trials are underway to achieve a seal at the base of store/release covers via heavy and controlled traffic-compaction of the top waste rock surface and/or by compacting mixtures of trafficked waste rock and topsoil.

\section{Conclusions}

In order to minimise risks to the environment and resources, the WWRD extension design has included a limestone base, lining of the main drainage channels to be buried by the dump with limestone to the full height of the dump, four cells to contain potentially acid forming (PAF) waste rock, limestone bunding on the dump perimeters and between PAF cells, and a $2 \mathrm{~m}$ thick store/release cover placed over the flat top surface of the dump. Innovative design components included allowing rainfall runoff from surrounding natural slopes rising above the rock dump to pass through the dump without intercepting the PAF waste rock, a store/release cover to reduce rainfall infiltration into the flat top surface of the completed dump and limit oxygen ingress, incorporating a failing Trial Pit Dump into the dump design to better manage the 
pre-existing ARD, and the inclusion for monitoring to check the performance of the WWRD extension for compliance and early detection of contaminated seepage for possible changes to the waste dump design.

SURPAC modelling was used successfully in designing the WWRD extension and can be used to make further adjustments and refinements as needed. This planning should help Zinifex Century mine achieve their long-term economic and environmental goals beyond the life of the mine.

\section{Acknowledgements}

The staff and management of Zinifex Century mine are acknowledged for their involvement in the work described in this paper and for allowing it to be published.

\section{References}

EGi (1997) Geochemical characterisation, classification and scheduling of waste rock. Report to Century Mine by Environmental Geochemistry International Pty Ltd, December 1997.

Williams, D.J. and Rohde, T.K. (2008) Rainfall infiltration into and seepage from rock dumps - A review. Proceedings First International Seminar on Rock Dumps, Stockpiles and Heap Leach Pads, A.B. Fourie (editor), Australian Centre for Geomechanics, Perth, Australia, 5-7 March 2008, 11 p.

Williams, D.J., Stolberg, D.J. and Currey, N.A. (2006) Long-term performance of Kidston's "store/release" cover system over potentially acid forming waste rock dumps. Proceedings of Seventh International Conference on Acid Rock Drainage, St Louis, Missouri, USA, 26-30 March 2006, pp. 2385-2396. 